\title{
Phlebotominae sand flies associated with a tegumentary leishmaniasis outbreak, Tucumán Province, Argentina
}

\author{
Flebotomíneos associados com surto de leishmaniose tegumentar, \\ na Província de Tucumán, Argentina
}

\author{
Oscar Daniel Salomón', María Gabriela Quintana², Isolina Flores ${ }^{3}$, \\ Ana María Andina ${ }^{4}$, Silvia Molina ${ }^{5}$, Lucía Montivero ${ }^{3}$ and Isabel Rosales ${ }^{6}$
}

\begin{abstract}
The distribution of sand flies and cases of tegumentary leishmaniasis in the area surrounding JB Alberd City, and the proximities of Catamarca province were studied, after an increase of reported cases from JB Alberdi, Tucumán province, in 2003. Of 14 confirmed cases, 57\% were females and 57\% were less than 15 years old, suggesting peridomestic transmission. However, $86 \%$ of them lived close to the Marapa river forest gallery and related wooded areas. Over 1,013 sand flies were collected; Lutzomyia neivai (Pinto, 1926) was prevalent at all the sites (92.3\%), while Lutzomyia migonei (França, 1920) (6.7\%) and Lu. cortelezzii (Brèthes, 1923) (1\%) were also found. The spatial distribution of Lu. neivai overlapped that of the cases, with higher abundance in microfocal hot spots close to the river in stable vegetated habitats or modified habitats with shadow and animal blood sources. The cumulative outcome of anthropic, ecological and climatic factors could have contributed to the onset of the outbreak.
\end{abstract}

Key-words: Tegumentary leishmaniasis. Phlebotominae. Lutzomyia. Argentina.

\section{RESUMO}

Após um aumento nos casos notificados na Cidade de JB Alberdi, Provincia de Tucumán, no ano de 2003, foram estudados a distribuição de flebotomíneos e casos de leishmaniose tegumentar nos arredores de JB Alberdi, e na área próxima à Província de Catamarca. De 14 casos confirmados, 57\% foram mulheres e 57\% tinham menos de 15 anos de idade, sugerindo transmissão peridomiciliar. Contudo, $86 \%$ dos casos residiam perto da galeria florestal do rio Marapa e perto de ilhas de vegetacão residual. De 1.013 flebotomíneos coletados, Lutzomyia neivai (Pinto, 1926) foi a espécie dominante em todos os sítios (92,3\%). Também, se capturaram Lutzomyia migonei (França, 1920) (6,7\%) e Lutzomyia cortelezzii (Brèthes, 1923) (1\%). A distribuicão espacial de Lu. neivai se sobrepõe com a dos casos com alta abundância em pontos quentes microfocais próximos ao rio, em habitats estáveis com vegetação, ou habitats modificados com sombras e fonte de sangue animal. O efeito acumulativo de fatores antrópicos, ecológicos e climáticos pode ter contribuido à geração do surto epidêmico.

Palavras-chaves: Leishmaniose tegumentar. Flebotomíneos. Lutzomyia. Argentina.

The first domestic focus of tegumentary leishmaniasis (TL) in Tucumán province was reported in 1949 by Romaña \& Ábalos ${ }^{19}$, involving dogs, humans and Lutzomyia (Evandromyia) cortelezzii (Brèthes, 1923) near the residences, but most of the TL cases were scattered in the region up to 1986 . Since then, in the southern Yungas montane foothills of the Tucumán-Catamarca area, several tegumentary leishmaniasis peridomestic outbreaks have taken place $^{12} 21$.

Lutzomyia (Nyssomyia) neivai (Pinto, 1926) (Lutzomyia intermedia sensu lato), Lutzomyia cortelezzii, Lutzomyia migonei (França, 1920) and Brumptomyia pintoi (Costa Lima, 1932) had been previously reported in Tucumán by $1947^{2}{ }^{8}$. Collections

\footnotetext{
1. Centro Nacional de Diagnóstico e Investigación en Endemoepidemias, ANLIS, Ministerio de Salud, Argentina. 2. INSUE, Instituto Miguel Lillo, Universidad Nacional de Tucumán, SM Tucumán, Argentina. 3. Ministerio de Salud Pública, SIPROSA, SM Tucumán, Argentina. 4. Hospital Miguel Belascuain, Concepción, Tucumán, Argentina. 5. Hospital de Clínicas Nicolás Avellaneda, SM Tucumán, Argentina. 6 Establecimiento Sanitario Dist Bañado de Ovanta, Catamarca, Argentina. ODS is member of "Carrera del Investigador Cientifico", Conicet.

Address to: Dr Oscar Daniel Salomón. CeNDIE. Av Paseo Colón 568. 1063, Buenos Aires, Argentina.

Tel: 541143312536 .

e-mail: danielsalomon@hotmail.com

Recebido para publicação em 13/4/2005

Aceito em 15/5/2006
} 
after 1990 reported Lutzomyia shannoni (Dyar, 1929), besides the previously cited species (except $\mathrm{Br}$. pintoi) ${ }^{12}$, and $\mathrm{Lu}$. neivai naturally infected with Leishmania (Viannia) braziliensis Vianna, $1911^{5}$. In Catamarca, only a single record of both $\mathrm{Lu}$. cortelezzii and $\mathrm{Lu}$. migonei was registered, from the village of Tapso ${ }^{19}$.

During 2003, an outbreak of TL was reported in JB Alberdi, Tucumán province. In this study the distribution of sand flies and cases in the JB Alberdi area, and the proximities of Catamarca province were studied the same year as the outbreak. The results are discussed in the framework of the time-space risk distribution and the regional epidemiological trends, in order to contribute to the design of appropriate surveillance and control strategies.

\section{MATERIAL AND METHODS}

Study area. Sand fly collections were performed in JB Alberdi county, Tucumán province, and Ali Jilan and Bañado de Ovanta villages in Catamarca province (Table 1). The region belongs to the anthropic modified foothills of the Yungas subtropical montane forest, in its southernmost region. Outside the natural reserve of the Escaba dam $(36 \mathrm{~km}$ from JB Alberdi, $\left.27^{\circ} 67^{\prime} \mathrm{S}, 65^{\circ} 77^{\prime} \mathrm{W}\right)$ the native vegetation remains in patches, mainly alongside the rivers and streams. Transitional vegetation with the eastern xerophytic forests is also present, but most of the land is highly degraded due to intensive agricultural cultivation (sugar cane, soybean, wheat, tobacco) ${ }^{36}$. Precipitation in the area is characterized by a monsoonal regime, with $60-90 \%$ of the total annual precipitation concentrated in the summer and early fall months (November-April) ${ }^{28}$.

Cases. Files of cases were investigated from the Concepción Hospital records and the Epidemiological Surveillance System of Tucumán province. The cases confirmed by parasitological diagnosis were visited, the houses georeferenced and the gender, age and date of ulcer appearance confirmed. The transmission scenario in Catamarca province was confirmed with local physicians.

Sand flies. Collections were performed with mini CDC light traps ${ }^{27}$ at 18 sites in Tucumán, sites 1-10 (Figure 1, Table 1) and Catamarca provinces, Ali Jilan sites 11-14 and Bañado de Ovanta sites 15-17 (Table 1). In Tucumán, the traps were placed overnight on two consecutive nights, and in Catamarca province, captures occurred on one night only, between October $28^{\text {th }}$ and November $1^{\text {st }}, 2003$. The minimal temperatures during collections days were $14-19^{\circ} \mathrm{C}$ and the maximal, $27-35^{\circ} \mathrm{C}$. The sites were associated with recent TL human cases, except Bañado de Ovanta (Catamarca), which was related to cases reported in 1999. The sites were rated according to their habitat suitability for sand flies with an empirical scale ranged from 1 to 4, which it was obtained by adding the following dichotomous attributes (presence 1, absence 0): a) river or stream at a distance $\leq 200 \mathrm{~m}$; b) surrounding land of $5 \mathrm{~m}$ width, surface shadowed by the canopy $\geq 70 \%$; c) patch of trees of at least $15 \mathrm{~m}$ in width and $5 \mathrm{~m}$ in length or dense patch of sugar cane of $2 \mathrm{~m}$ in diameter; d) a resting place for domestic animal

\begin{tabular}{|c|c|c|c|c|c|c|c|}
\hline Habitat rate & Site & Coordinates & Lu. neivai & Lu. migonei & Lu. cortelezzii & Relative capture (\%) & $\mathrm{F} \%$ \\
\hline \multirow[t]{2}{*}{4} & 1 & $27^{\circ} 38^{\prime} 13^{\prime \prime} \mathrm{S}$ & 339 & 24 & 3 & 100.0 & 54.6 \\
\hline & & $65^{\circ} 39^{\prime} 23^{\prime \prime} \mathrm{W}$ & $(92.6)$ & (6.6) & $(0.8)$ & & \\
\hline \multirow[t]{2}{*}{4} & 2 & $27^{\circ} 37^{\prime} 59^{\prime \prime} \mathrm{S}$ & 333 & 21 & 4 & 98.2 & 47.4 \\
\hline & & $65^{\circ} 39^{\prime} 14^{\prime \prime} \mathrm{W}$ & $(93.0)$ & $(5.9)$ & (1.1) & & \\
\hline \multirow[t]{2}{*}{3} & 3 & $27^{\circ} 37^{\prime} 14^{\prime \prime} \mathrm{S}$ & 165 & 18 & 1 & 48.7 & 57.6 \\
\hline & & $65^{\circ} 41^{\prime} 29^{\prime \prime} W$ & $(89.7)$ & $(9.8)$ & $(0.5)$ & & \\
\hline \multirow[t]{2}{*}{2} & 4 & $27^{\circ} 37^{\prime} 43^{\prime \prime} \mathrm{S}$ & 53 & 0 & 0 & 15.6 & 41.5 \\
\hline & & $65^{\circ} 40^{\prime} 31^{\prime \prime} \mathrm{W}$ & $(100.0)$ & & & & \\
\hline \multirow[t]{2}{*}{2} & 5 & $27^{\circ} 37^{\prime} 22^{\prime \prime} \mathrm{S}$ & 21 & 2 & 1 & 6.2 & 52.3 \\
\hline & & $65^{\circ} 36^{\prime} 21^{\prime \prime} 0$ & $(87.5)$ & (8.3) & $(4.2)$ & & \\
\hline \multirow[t]{2}{*}{2} & 6 & $27^{\circ} 37^{\prime} 22^{\prime \prime} \mathrm{S}$ & 7 & 1 & 1 & 2.1 & \\
\hline & & $65^{\circ} 36^{\prime} 00^{\prime \prime} \mathrm{W}$ & (77.8) & (11.1) & (11.1) & & \\
\hline \multirow[t]{2}{*}{1} & 9 & $27^{\circ} 33^{\prime} 15^{\prime \prime} \mathrm{S}$ & 5 & 0 & 0 & 1.5 & \\
\hline & & $65^{\circ} 37^{\prime} 05^{\prime \prime} \mathrm{W}$ & $(100.0)$ & & & & \\
\hline \multirow[t]{2}{*}{0} & 7 & $27^{\circ} 35^{\prime} 28^{\prime \prime} \mathrm{S}$ & 0 & 0 & 0 & 0 & \\
\hline & & $65^{\circ} 36^{\prime} 00^{\prime \prime} \mathrm{W}$ & & & & & \\
\hline \multirow[t]{2}{*}{0} & 8 & $27^{\circ} 35^{\prime} 48^{\prime \prime} \mathrm{S}$ & 1 & 0 & 0 & 0.3 & \\
\hline & & $65^{\circ} 37^{\prime} 24^{\prime \prime} \mathrm{w}$ & $(100.0)$ & & & & \\
\hline \multirow[t]{2}{*}{0} & 10 & $27^{\circ} 32^{\prime} 35^{\prime \prime} \mathrm{S}$ & 1 & 0 & 0 & 0.3 & \\
\hline & & $65^{\circ} 36^{\prime} 54^{\prime \prime} \mathrm{W}$ & $(100.0)$ & & & & \\
\hline \multirow[t]{2}{*}{2} & 11 & $28^{\circ} 08^{\prime}-10^{\prime} \mathrm{S}$ & 10 & 2 & 0 & & \\
\hline & 14 & $65^{\circ} 29^{\prime}-30^{\prime} \mathrm{W}$ & $(83.3)$ & $(16.7)$ & & & \\
\hline \multirow[t]{2}{*}{$\overline{0}$} & 15 & $29^{\circ} 03^{\prime}-05^{\prime} \mathrm{S}$ & 0 & 0 & 0 & & \\
\hline & 17 & $65^{\circ} 18^{\prime}-19^{\prime} \mathrm{W}$ & & & & & \\
\hline
\end{tabular}


(pigs, goats, horses, chickens) or minimally disturbed vegetation of $50 \mathrm{~m}^{2}$. All captured sand flies were dry stored until identification using the keys of Young and Duncan ${ }^{31}$, with modifications by Marcondes ${ }^{13}$.

Additional data sources. The population numerator for the computed incidence rate was taken from the National Institute of Statistics and Census ${ }^{11}$. Weather data were provided by Servicio Meterologico Nacional, Fuerza Aerea Argentina, from the station at San Miguel de Tucumán $\left(26^{\circ} 50^{\prime} \mathrm{S}, 65^{\circ}\right.$ $12^{\prime} \mathrm{W}$ ), whose records are representative of rainfall patterns throughout the region ${ }^{10}$.

Data analysis. The Fisher's exact test and $\chi^{2}$ test were used for bivariate analysis. All statistical tests were considered significant at $P<0.01$.

\section{RESULTS}

Tucumán province reported 33 cases of TL during 2003, 14 of them clustered around JB Alberdi village, with over 23 suspected cases in the area. Patient age in these cases ranged from two to 54 years old, 8/14 were less than 15 years old and $8 / 14$ were females. Their spatial distribution shows two cases of residents in an urban area (JB Alberdi and Villa Belgrano) and the remaining 12 (85.7\%) related to the river Marapa, four of them within a radius of $0.5 \mathrm{~km}$, and 13 within a radius of $2 \mathrm{~km}$ (Figure 1). Taking into account the population of the two villages involved $(18,348)$ the urban incidence during 2003 was $0.01 \%$, while the rural incidence was $0.12 \%$, if the remaining population of JB Alberdi county $(9,858)$

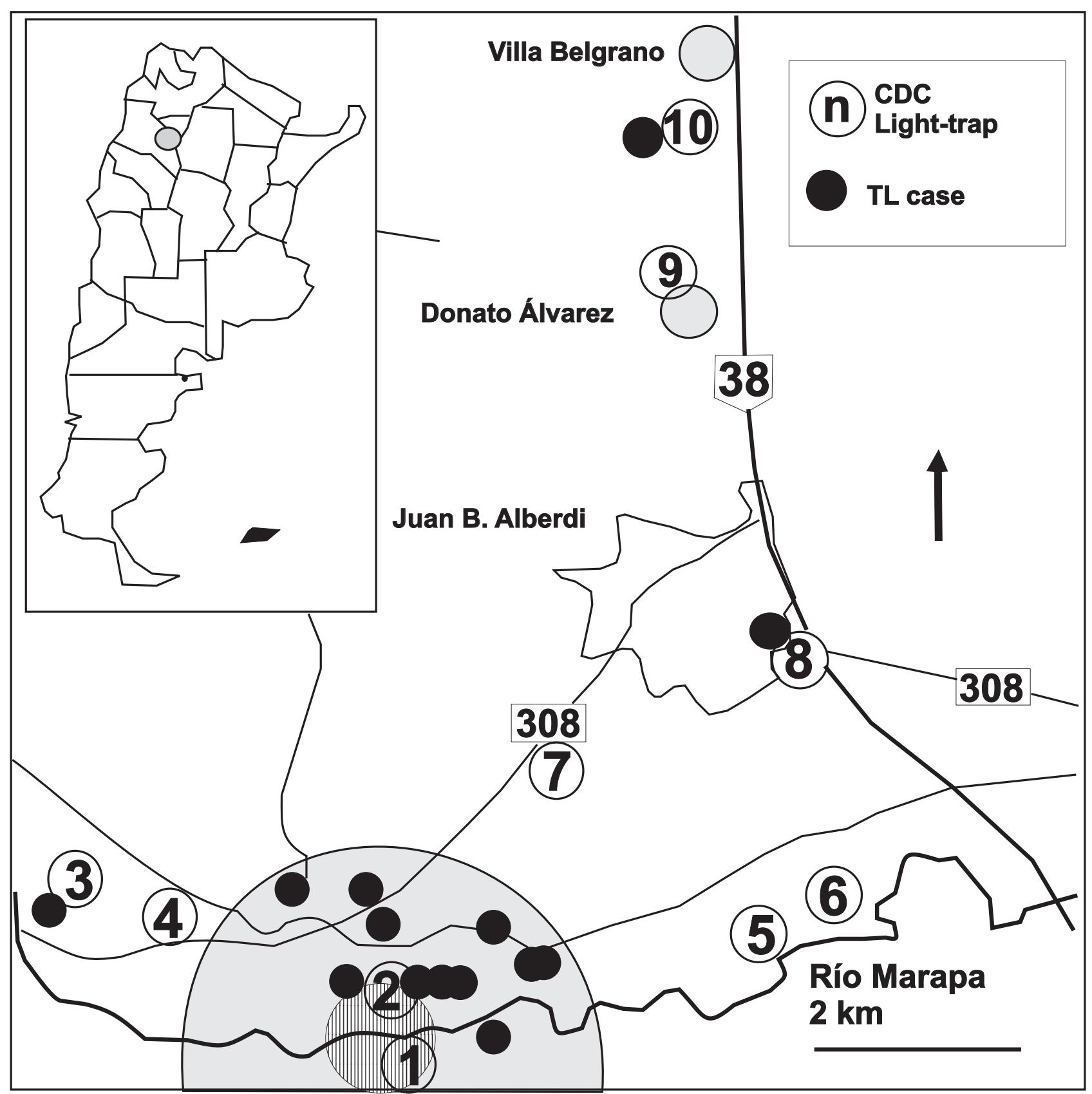

Figure 1 - Map of the Tucumán study area showing the location of cases (black dots), the phlebotomine capture sites (numerated according to Table 1 ), and the areas of 0.5 and $2 \mathrm{~km}$ where the cases and larger population of phlebotomine were clustered. In the right corner map of Argentina with the Tucumán-Catamarca study area encircled. 
was equally exposed, although actually less than $20 \%$ of this figure live close to the Marapa river. Diagnosis took place between March and September, however the appearance of ulcers occurred in April for 8 cases, June for 2, and a single case in October 2002, March, July and August 2003 (Figure 2). The cumulative rainfall during the season 2001-2002 (November-October) was significantly higher than that of 2002-2003 (Figure 2), while the temperature records did not differ between these periods.

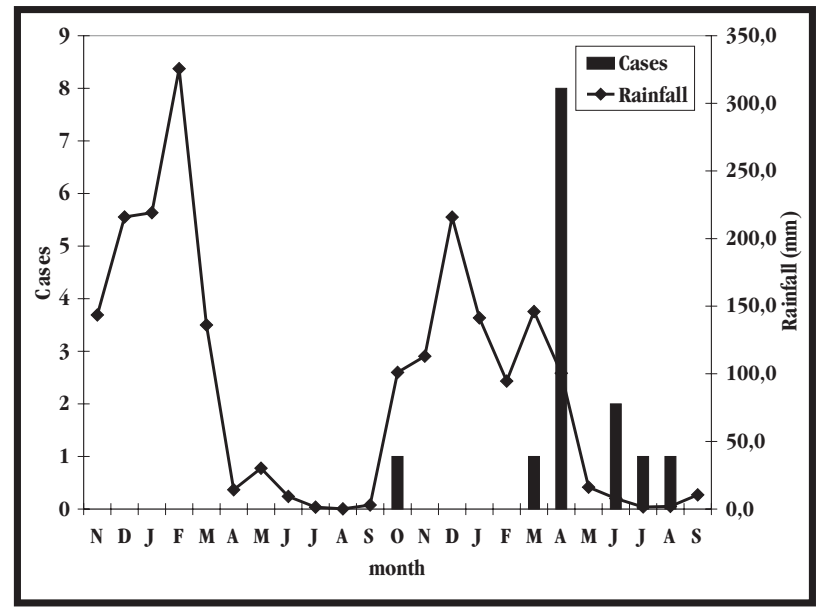

Figure 2 - Cumulative rainfall $(\mathrm{mm})$ and tegumentary leishmaniasis cases by month since November 2001 to September 2003, JB Alberdi, Tucumán, Argentina.

Captures produced a total of 1,013 sand flies of three species: Lu. neivai $92.3 \%$, Lu. migonei 6.7\%, and Lu. cortelezzii $1 \%$ (Table 1). The prevalent species at all the sites was Lu. neivai, which was also the only species found in peridomestic degraded habitats far away form the river (sites 8, 9, 10 Figure 1 and Table 1) or in small patches of vegetation less than $10 \mathrm{~m}$ wide (site 4). On the other hand, all three species together were found only in habitats close to the Marapa river, with dense vegetation coverage or patches with relatively less anthropic degradation. Lu. neivai abundance increased as the habitat rate scale increased (CR, Table 1).

The species proportion did not differ significantly among sites where the three species were found together and traps collected more than 10 insects; $L u$. neivai relative abundance ranged from $87.5 \%$ to $93 \%$ of the whole capture. The female proportion of $\mathrm{Lu}$. neivai did not differ either, despite the fact that one of the two sites with highest captures was in a large undisturbed vegetated area and the other was close to the house of three cases with several pig dwellings.

The captures made in Catamarca province are not quantitatively comparable with those of Tucumán province, because the former occurred on a single stormy night. However, Lu. neivai and Lu. migonei were found in Ali Jilan, where TL cases were reported during 2003.

\section{DISCUSSION}

Cases of TL were clustered in the JB Alberdi area in both time and space during 2003. The main TL transmission period took place during the first half of the fall of 2003. The age and gender distribution of the cases suggests peridomestic transmission. The spatial distribution of cases shows a strong risk association with the Marapa river forest gallery, probably in scattered hot spots. The urban cases may be due to behavioral risk related to the river or to a periurban transmission of low probability, even during high transmission periods.

The TL cases reported from Tucumán province to the National System of Epidemiological Surveillance (SINAVE), show four periods with more than 15 cases/year since 1970: 1986-1988 (125 cases), 1991-1992 (88 cases), 1995-1997 (81 cases), 2003-2004 (83 cases). Although transmission seems to be distributed along the SW-NE axis of the foothills of Yungas montane forest since the first reports ${ }^{19}{ }^{29}$, for at least the two last epidemic waves the cases were concentrated in the southern region from April to June, where cases were also present during inter-epidemic years (data from Tucumán Epidemiological Surveillance System). Catamarca province, with a smaller area of transmission and less populated than the Tucumán area, also showed a peak in the period 19861988 (135 cases) and 5-7 cases/year in 1990-1992, 1999 and 2003 (SINAVE). Thus, leishmaniasis is endemic in the region between $27^{\circ}$ and $29^{\circ} \mathrm{S}$, but parasite circulation increased with epidemic outbreaks during the last decade in this area of transitional vegetation and intensive agriculture land use.

Three out of the five recorded species for the province were collected in the present work. Brumptomyia pintoi was reported in the 1940 's for the last time ${ }^{2}$, and a single individual of $\mathrm{Lu}$. shannoni was collected between 2001-2003 in the studied area ${ }^{12}$. In contrast, $L u$. cortelezzii was reported for the first time in the province since 1943, although in the captures related to the JB Alberdi TL outbreak, Lu. neivai was the most abundant species and the only species found in highly disturbed habitats, such as periurban vegetation.

Lutzomyia neivai has a great capacity for adaptation to human modified environments, it was incriminated as a vector of L. (V.) braziliensis in several TL foci in Argentina ${ }^{2122}$, and it was found naturally infected in Tucumán in the study area near site $1^{5}$. Lu. migonei, was also present in the sites close to cases; it has been found naturally infected in Brazil ${ }^{1}$, where it was implicated as vector ${ }^{17}$. Thus, $\mathrm{Lu}$. migonei might play a role as a secondary vector, it could be required to sustain the zoonotic cycle during interepidemic periods, or it could be a hinge species between the zoonotic cycle and human transmission ${ }^{4}$.

The spatial distribution of sand flies indicates that the highest abundance was found in the forest gallery and adjacent forested places of the Marapa river, associated with the size, density, stability and contiguity of the patches of secondary forest. The risk of an effective human-Phlebotominae contact decreases consistently from the river to the periurban area and nearby villages. This risk could also be increased by a peak of sand flies due to the rainfall pattern and/or to the reduction of insectivores.

In relation to the rainfall pattern in northwestern Argentina, Lu. neivai showed a positive association between an above average rainfall peak, or difference between years, and sand fly abundance 
during the fall of the following year, the season of highest risk $^{23}$. The time relationship between the rainfall and the cases in this outbreak, was consistent both with the lag between the precipitation and the time of appearance of cases during the fall (Figure 2). In the study area, forest fires also showed an association of a year lag with unusual rainfall peaks, when young trees (fuels) invade shrublands under conditions of increased moisture availability ${ }^{10}$, a scenario that might also enlarge the sand fly breeding area.

In relation to insectivore abundance, until 2001 a stable population of the bat Tadarida brasiliensis (Saint-Hilaire, 1824) inhabited the Escaba Dam structure. It was estimated to be 10-12 x $10^{6}$ individuals, which ate 7,000kg/insects/day (Bárquez R: unpublished report cited in ${ }^{7}$ ). During July and November 2002 the bats were relocated from inside the dam, although the law protected these populations ${ }^{18}$. The current population, after relocation was estimated to be $0.45-0.90 \times 10^{6}$ individuals (Mosa S, Regidor H, Núñez F: unpublished report cited in ${ }^{9}$ ). T. brasiliensis eats mostly moths and other insects between 5 and $9 \mathrm{~mm}$ long $^{30}$, so phlebotomine are probably excluded from their diet. However, the bat may be a significant blood source for sand flies ${ }^{1420}$, thus the relocation and radical reduction in the Tadarida populations could have impacted the abundance and dispersion of phlebotomine. Furthermore, $L u$. neivai abundance in time and space is consistent with a metapopulation distribution ${ }^{23}$, so the Escaba reserve and the gallery forest of the dam basin, including the Marapa river, may constitute a source population.

In Catamarca, there was a single registration of $\mathrm{Lu}$. cortelezzii and $\mathrm{Lu}$. migonei from $1943^{19}$, therefore this is the first report of $L u$. neivai and $L u$. migonei in the active TL transmission area of this province (cases 2002-2003). No sand flies were collected in the locations that reported TL cases in 1999 (Bañado de Ovanta), but the place has been intensively deforested and the land eroded by droughts since the transmission period.

The TL outbreaks took place due to the cumulative effects of anthropic, ecological and climatological variables. The southern region of Tucumán province was endemic for TL transmission, and $L u$. neivai, a vector of $L$. (V.) braziliensis, was concentrated in patches of trees, although it can colonize peridomestic habitats. During the fall of 2003, $\mathrm{Lu}$. neivai populations close to JB Alberdi city might have been unusually high due to the 2002-2003 rainfall pattern and the 2002 insectivore depletion. Human activities associated with Marapa river hot spots from dusk to dawn, including subsistence, religious pilgrimage and recreation, after the summer rains, increased the risk of transmission. Reservoirparasite distribution might also have been modified by the climatological and ecological disturbances.

From a regional point of view, the frequency and intensity of tegumentary outbreaks has increased in Argentina since 1970. The increase in precipitation during the three last decades of the $20^{\text {th }}$ century has been also unprecedented for the past 200 years, with a jump (variation 26\%) around $1956^{1528}$. This period may be close to being reverted, as long periods of excess or deficit in precipitations might have recurrence intervals every 54-65 years ${ }^{17}$. On the other hand, the species diversity is the same along the $700 \mathrm{~km}$ of the Yungas from the Bolivian border, despite the high local endemicity and the north-south discontinuity ${ }^{3}$. Thus, species such as $\mathrm{Lu}$. neivai and $\mathrm{Lu}$. migonei, adapted to human modified habitats, could colonize new areas from long term refugees to drier vegetated environments, as the rainfall increases. Furthermore, agricultural practices maintain vegetal corridors to prevent fire, wind and to protect stream banks, thus concentrating vectors and potential reservoirs without predator control, and creating hot spots ${ }^{25} 26$. Focal deforestation for citrus culture in Tucumán grew during the 1980s and 1990s in the transitional forests along the western foothills. In JB Alberdi county, 2,590 hectares were deforested from 1990 to 2002, and the potential remaining area for deforestation is less than 300 hecteares ${ }^{24}$.

In conclusion, TL endemic transmission and epidemic episodes will continue in the southern Yungas region and the transitional area to the west. The outbreaks may involve urban population and large areas, however the main source of transmission seems to be spatially restricted to small foci related to the vector and eventual reservoir abundance. This space and time (fall) risk concentration should be taken into account with regard to surveillance and interventional strategies, both for vector monitoring and control, and for recommendations regarding the avoidance of risk behaviors.

\section{ACKNOWLEDGEMENTS}

The authors are grateful to the National Coordination of Vector Control team, Dr M. Zaidenberg, Mr J. Zárate (Tucumán delegation) and especially Mr R. Moya, for the operational support and technical collaboration. The authors also thank the teams of JB Alberdi Hospital, Drs A. Tilca, R. Villafañe, P.H.C agents A. Martínez, R. Fenoglio, S. Fenoglio; JB Alberdi Municipality Lic. M. Victoria; Concepción Hospital Drs A.M. Cadiñano, D. Agu, L. Grellet de Canseco, M. Lazarte; Catamarca P.H.C. Ayosa.

\section{REFERENCES}

1. Azevedo AC, Rangel EF, Queiroz RG. Lutzomyia migonei (França 1920) naturally infected with peripylarian flagellates in Baturité, a focus of cutaneous leishmaniasis in Ceará State, Brazil. Memórias do Instituto Oswaldo Cruz 85: 479, 1990.

2. Bejarano JFR, Duret JP. Contribución al conocimiento de los flebótomos argentinos (Diptera, Psychodidae). Revista Sanidad Militar Argentina 49: 327-336, 1950.

3. Brown AD, Grau HR, Malizia LR, Grau A. Argentina. In: Kappelle M, Brown AD (eds) Bosques nublados del neotrópico. INBio, Costa Rica, p. 623-659, 2001.

4. Cháves LF, Añez N. Species co-occurrence and feeding behavior in sand fly transmission of American cutaneous leishmaniasis in western Venezuela. Acta Tropica 92: 219-224, 2004.

5. Córdoba-Lanús E, De Grosso ML, Piñero JE, Valladares B, Salomón OD. Natural infection of Lutzomyia neivai with Leishmania spp in northwestern argentina. Acta Tropica 98: 1-5, 2006.

6. Cabrera A. Regiones fitogeográficas de la República Argentina. Enciclopedia de Agricultura, Jardinería y Fruticultura 2, Acme Buenos Aires, Argentina, 1976. 
7. Congreso de la Nación Argentina. Honorable Camara de Diputados. Labor Parlamentaria del Diputado de la Nación Dr Florencio Aceñolaza. Período diciembre 1991-diciembre 1992. Talleres de la imprenta del Congreso de la Nación, p. 107-112, 1993.

8. Duret JP. Notas sobre flebótomos argentinos. Revista Sanidad Militar Argentina 51: 534-536, 1952

9. Elsinger R. Polémica por colonia de murciélagos en Tucumán. Clarín Sección Sociedad 21/4/2003 Año VII No 2576. http://old.clarin.com/diario/ 2003/04/21/s-03401.htm, 2003.

10. Grau HR, Veblen TT. Rainfall variability, fire and vegetation dynamics in neotropical montane ecosystems in north-western Argentina. Journal of Biogeography 27: 1107-1121, 2000.

11. Instituto Nacional de Estadísticas y Censos. Censo Nacional de Población y Vivienda 2001. CD-ROM No 24 Tucumán. INDEC, Buenos Aires, Argentina, 2004.

12. Lanús EC, Salomón OD. Phlebotominae Fauna in the Province of Tucumán, República Argentina. Revista do Instituto de Medicina Tropical São Paulo 44: 23-27, 2002

13. Marcondes CB. Redescription of Lutzomyia (Nyssomyia) intermedia (Lutz \& Neiva, 1912), and resurrection of $L$. neivai (Pinto, 1926) (Diptera, Psychodidae, Phlebotominae). Memórias do Instituto Oswaldo Cruz 97: 457-462, 1996.

14. Memmott J. Sandfly distribution and abundance in a tropical rain forest. Medical and Veterinary Entomology 5: 403-411, 1991.

15. Minetti JL, Vargas WM. Trends and jumps in the annual precipitation in South America, south of the $15^{\circ}$ S. Atmósfera 11: 205-221, 1997

16. Minetti JL, Vargas WM, Poblete AG, Acuña LR, Casagrande G. Non-linear trend and low frequency oscillations in annual precipitation over Argentina and Chile, 1931-1999. Atmósfera 16: 119-135, 2003.

17. Peterson AT, Shaw J. Lutzomyia vectors for cutaneous leishmaniasis in Southern Brazil: ecological niche models, predicted geographic distributions, and climate change effects. International Journal of Parasitology 33: 919-931, 2003

18. Regidor H, Mosa S, Nuñez A. Reubicación y confinamiento de una colonia de Tadarira brasiliensis, una alternativa de manejo compatible con la conservación. In: Resúmenes de las XVIII Jornadas Argentinas de Mastozoología. La Rioja, p. 74, 2003.

19. Romaña C, Abalos JW. Distribución de flebótomos y leishmaniosis tegumentaria en Argentina. Anales del Instituto de Medicina Regional 2: 293-302, 1949
20. Rotureau B. Ecology of the Leishmania species in the guianan ecoregion complex. The American Journal of Tropical Medicine and Hygiene 74: 81-96, 2006

21. Salomón OD. Leishmaniosis: vectores y brotes epidémicos en Argentina. In: Salomón OD (ed) Actualizaciones en Artropodología Sanitaria Argentina. Fundación Mundo Sano, Buenos Aires, p. 185-196, 2002.

22. Salomón OD. Phlebotominae. In: González A, Villalobos C, Ranaletta MA (eds) Ectoparasitosis Humanas. Ediciones Científicas Americanas, Buenos Aires, p. 121-144, 2003.

23. Salomon OD, Wilson ML, Munstermann LE, Travi BL. Spatial and Temporal Patterns of Phlebotominae Sand Flies (Diptera: Psychodidae) in a Cutaneous Leishmaniaisis Focus in Northern Argentina. Journal of Medical Entomology 41: 33-39, 2004.

24. Soria F, Fandos C, Scandaliaris J. Frontera agrícola-ganadera en la Provincia de Tucumán: Su evolución entre los años 1990 a 2002 y determinación de áreas con posibilidades de ser incorporadas a la actividad agropecuaria. Estación Experimental Agroindustrial Obispo Colombres (EEAOC). Avance Agroindustrial p. 41-45, 2003.

25. Sosa-Estani S, Salomón OD. Aspectos clínicos, epidemiológicos y entomológicos de la transmisión de la leishmaniosis en la República Argentina. Sociedad Iberoamericana de Información Científica (SIIC), Sección Expertos Invitados, (http://www.siicsalud.com/main/expinv.htm), 2002.

26. Sosa-Estani S, Salomón OD, Gómez A0, Esquivel ML, Segura EL. Diferencias regionales y Síndrome Pulmonar por Hantavirus (enfermedad emergente y tropical en Argentina). Cadernos de Saúde Pública 17 (supl): 47-57, 2001.

27. Sudia WD, Chamberlain RW. Battery operated light trap, an improved model. Mosquito News 22: 126-129, 1962.

28. Villalba R, Grau HR, Bonisegna JA, Jacoby GC, Ripalta A. Tree-ring evidence for long-term precipitation changes in subtropical South America. International Journal of Climatology 18: 1463-1478, 1998.

29. Villalonga JF. Leishmaniosis Tegumentaria Americana: Clínica y Tratamiento. Revista de la Facultad de Medicina 6: 197-208, 1963.

30. Wilkins KT. Tadarida brasiliensis. Mammalian species 331: 1-10, 1980.

31. Young DG, Duncan MA. Guide to the Identification and Geographic distribution of Lutzomyia sand flies in Mexico, the West Indies, Central and South America (Diptera:Psychodidae). Memories of the American Entomologic Institute 54:1-881, 1994. 